\title{
Maternal and perinatal outcome in severe preeclampsia and eclampsia at the Rivers State university teaching hospital, Nigeria
}

\author{
Peter A. Awoyesuku*, Dickson H. John, Lewis B. Lebara
}

Department of Obstetrics and Gynecology, Rivers State University Teaching Hospital, Port-Harcourt, Rivers State, Nigeria

Received: 08 September 2020

Accepted: 08 October 2020

*Correspondence:

Dr. Peter A. Awoyesuku,

E-mail: pawoyesuku@yahoo.co.uk

Copyright: (c) the author(s), publisher and licensee Medip Academy. This is an open-access article distributed under the terms of the Creative Commons Attribution Non-Commercial License, which permits unrestricted non-commercial use, distribution, and reproduction in any medium, provided the original work is properly cited.

\begin{abstract}
Background: Severe preeclampsia and eclampsia remain a challenge in tropical obstetric practice. It is a major contributor to feto-maternal morbidity and mortality in developing countries. This study seeks to determine the prevalence, associated risk factors and the feto-maternal outcome of severe preeclampsia and eclampsia at the rivers state university teaching hospital (RSUTH).

Method: A retrospective study of all women who had severe preeclampsia and eclampsia and were delivered at the RSUTH in a two-year period, $1^{\text {ST }}$ January 2018 to $31^{\text {ST }}$ December 2019, was carried out. Data on patients' age, parity, education, booking status, gestational age at delivery, diagnosis, complications, mode of delivery and fetal sex, birth weight and Apgar scores were retrieved using structured pro-forma. Data were analyzed using SPSS version 20.

Results: There were 4496 deliveries of which 128 had severe preeclampsia and eclampsia, giving a prevalence of $2.85 \%$. Of these, $94(73.4 \%)$ had severe preeclampsia and $34(26.6 \%)$ had eclampsia. The mean age of the women \pm SD was $29.84 \pm 5.44$ years, median parity was para 1 , and mean gestational age \pm SD was $35.38 \pm 3.84$ weeks. There were 10 maternal deaths giving case fatality of $7.8 \%$. The mean birth weight \pm SD was $2.61 \pm 0.91 \mathrm{~kg}$ and stillborn rate was $14.4 \%$. There was significant association with maternal age, education, booking status, method of delivery and Apgar score of the baby.

Conclusion: The prevalence in this study is high with associated high maternal mortality and stillborn rates. Timely and appropriate intervention including primary management and judicious termination of pregnancy will reduce mortality of mother and fetus.
\end{abstract}

Keywords: Severe preeclampsia, Eclampsia, Risk factors, Maternal outcome, Perinatal outcome

\section{INTRODUCTION}

Preeclampsia is a hypertensive disorder of pregnancy, which usually manifest after 20 weeks of gestation with hypertension and proteinuria, in a previously normotensive woman. ${ }^{1}$ Hypertension being defined as blood pressure $\geq 140 \mathrm{mmHg}$ for systolic and/or $90 \mathrm{mmHg}$ for diastolic on at least two occasions and at least 4-6 hours apart. ${ }^{2}$ Preeclampsia is considered severe if blood pressure and proteinuria are increased substantially (BP $\geq 160 / 100 \mathrm{mmHg}$ and $\geq 5 \mathrm{gm}$ protein in 24 hours urine sample or $2+$ on single sample), or symptoms of end organ damage like thrombocytopenia, altered liver function, oliguria, cerebral or visual disturbances, pulmonary oedema and fetal growth restriction are present. ${ }^{2,3}$ When convulsions occur in addition to these signs of preeclampsia, the condition is referred to as eclampsia.,

Preeclampsia is primarily a disorder of nulliparous, but multiparous pregnant women with a new partner have an elevated risk of preeclampsia like that of nulliparous women. ${ }^{6}$ Preeclampsia complicates $10 \%$ of all pregnancies; it was found that $3-5 \%$ of first pregnancies and $1 \%$ of subsequent pregnancies are complicated by preeclampsia. ${ }^{7}$ The incidence of preeclampsia/eclampsia 
remains high in developing countries like Nigeria because of poor antenatal attendance. Incidence of 0.42 , 1.32 and $1.66 \%$ have been reported in Kaduna, Benin, and Lagos. ${ }^{8-10}$ Studies have shown that the incidence was higher among primigravidae and young women less than 25 years of age. ${ }^{8,11}$ It has also been reported as a leading cause of maternal mortality in Kano, Sokoto, Jos and Port Harcourt. ${ }^{12-15}$

There is currently no single cost-effective and reliable screening test for preeclampsia and there are no wellestablished measures for primary prevention. Access to antenatal care, early detection of the disorder, careful monitoring and appropriate management are crucial elements in prevention of preeclampsia related deaths. In this center patients are managed as per existing protocol after proper history, examination, and investigations. Antihypertensive of choice are alpha methyldopa, oral nifedipine and labetalol. Based on the findings of a clinical trial involving our center, ${ }^{16}$ magnesium sulphate is being used as anti-convulsant.

The ultimate treatment for preeclampsia, to prevent maternal complications, is to deliver the patient. However, delivery is not always in the best interest of the fetus. The rationale for delaying delivery in these patients is to allow for more fetal maturity and reduce perinatal morbidity and mortality, which includes iatrogenic prematurity, respiratory distress syndrome (RDS), intrauterine growth restriction (IUGR), intrauterine asphyxia and intrauterine death (IUD). Maternal complications include cerebrovascular accidents (CVA), acute renal failure (ARF), hemolysis, elevated liver enzymes and low platelets (HELLP) syndrome and premature separation of placenta. ${ }^{17}$

Because of the high maternal and fetal complications associated with severe preeclampsia and eclampsia, it is necessary to evaluate and understand some of the factors influencing the prevalence and outcomes of management to proffer solutions to limit the impart of the disease. This study, therefore, seeks to determine the rate of severe preeclampsia and eclampsia in women delivering at RSUTH, evaluate the associated risk factors and analyse the maternal and perinatal outcome in these women. The findings of this study will help to formulate strategies to improve the maternal and perinatal outcomes in cases of severe preeclampsia and eclampsia.

\section{METHODS}

This study was conducted at the labour ward of the RSUTH, a tertiary hospital owned and funded by the government of Rivers State. Patients are expected to pay directly for services they receive (except few that participate in the national health insurance scheme). The hospital provides emergency obstetric services to women referred from other centers, as well as providing antenatal care and delivery services for low and high-risk pregnant women booked with the hospital. The hospital is well equipped and has availability of qualified team comprising of obstetricians, paediatricians and anaesthetists. There is availability of laboratory and blood bank services in the hospital. The labour ward is open 24 hours/7 days, and there is an average annual delivery of over 1000 women.

A retrospective descriptive study over a two-year period, from $1^{\text {st }}$ January 2018 to $31^{\text {st }}$ December 2019 , was carried out. The study population were pregnant women with severe preeclampsia and eclampsia admitted and managed at the labour ward of the RSUTH. Those with complete records were included, while those with incomplete data, postpartum eclampsia, history of previous renal disease or seizure disorders were excluded.

Data was retrieved from the hospital records (birth registers) and case notes of the patients who had severe preeclampsia and eclampsia within the study period using a structured proforma data sheet. Information on maternal age, parity, education, booking status, Gestational age at presentation, diagnosis, complications, mode of delivery (SVD or CS) and fetal sex, birth weight, Apgar scores and admission to SCBU were extracted.

Coded data were entered into excel spreadsheet and exported to SPSS version 20 for statistical analysis. Descriptive statistics such as mean, and frequencies were used to present the results in tables and figures. Crosstabulation was used to determine associations between different variables by Fisher's exact test or chi-square test, as appropriate, at statistical significance level of $\mathrm{p}<0.05$.

\section{RESULTS}

During the two-year period, there were a total of 4496 maternal deliveries of which 128 had severe preeclampsia and eclampsia, giving an incidence of $2.85 \%$. Of the 128 women, $94(73.4 \%)$ had severe preeclampsia (prevalence of $2.09 \%)$ and $34(26.6 \%)$ presented with eclampsia (prevalence of $0.76 \%$ ), see (Figure 1). The mean age of the women \pm SD was $29.84 \pm 5.44$ years, median age of 30 years and age range was 16-42 years. The median parity was para 1; range was para 1-8. The mean gestational age \pm SD was $35.38 \pm 3.84$ weeks; range was $20-42$ weeks. Majority of the women had secondary education (45.3\%), were having their first delivery $(57.0 \%)$, were delivered preterm $(73.4 \%)$, were booked patients $(74.2 \%)$ and were delivered by caesarean section $(75.8 \%)$. The demographic characteristics of the women is as shown in (Table 1).

From the 128 women, $125(97.7 \%)$ neonates were delivered while $3(2.3 \%)$ were undelivered, as their mothers died undelivered. The mean birth weight of the neonates $\pm \mathrm{SD}$ was $2.61 \pm 0.91 \mathrm{~kg}$, median birth weight was $2.60 \mathrm{~kg}$ and birthweight range was $0.5-5.0 \mathrm{~kg}$. Of the $125(97.7 \%)$ babies delivered, $18(14.4 \%)$ were stillborn; $13(10.4 \%)$ males and $5(4.0 \%)$ females. The proportion 
of male to female babies delivered was almost 50:50, majority (59.25) had birth weights $\geq 2500$ gm, (72.7\%) had good Apgar score $(\geq 7)$, while only a marginal proportion $(50.5 \%)$ required admission to neonatal intensive care (SCBU). The neonatal outcomes are as shown in (Table 2).

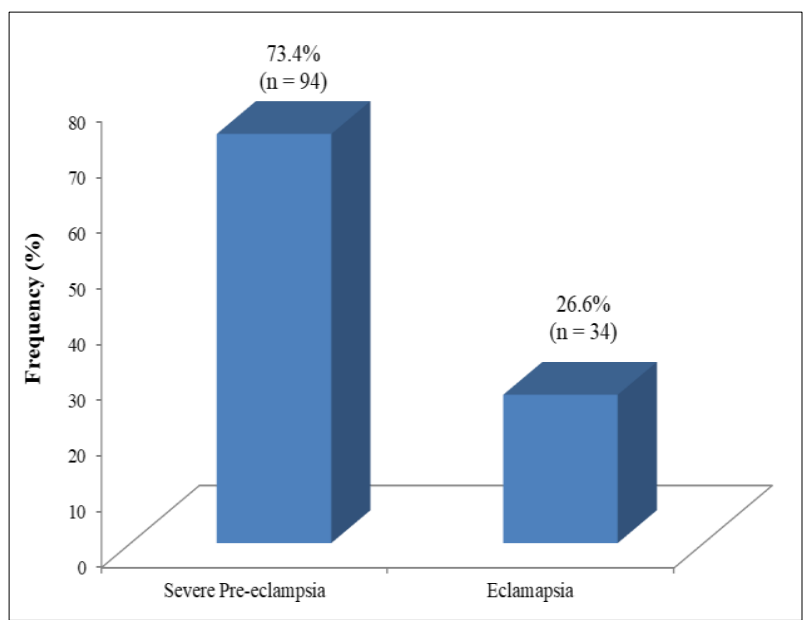

Figure 1: Occurrence of severe pre-eclampsia and eclampsia among women at RSUTH.

Table 1: Demographic characteristics of women with preeclampsia/eclampsia at RSUTH.

\begin{tabular}{|c|c|c|}
\hline Variables $(n=128)$ & Frequency & Percentage (\%) \\
\hline \multicolumn{3}{|l|}{ Age (years) } \\
\hline$<20$ & 6 & 4.7 \\
\hline $20-29$ & 52 & 40.6 \\
\hline $30-39$ & 68 & 53.1 \\
\hline$\geq 40$ & 2 & 1.6 \\
\hline \multicolumn{3}{|l|}{ Educational level } \\
\hline Primary & 43 & 33.6 \\
\hline Secondary & 58 & 45.3 \\
\hline Tertiary & 27 & 21.1 \\
\hline \multicolumn{3}{|l|}{ Parity } \\
\hline Para 1 & 73 & 57.0 \\
\hline Para 2-4 & 53 & 41.4 \\
\hline Para $\geq 5$ & 2 & 1.6 \\
\hline \multicolumn{3}{|c|}{ Median=para 1; Range=para $1-8$} \\
\hline \multicolumn{3}{|c|}{ Gestational age at delivery (Week) } \\
\hline$\leq 36$ & 94 & 73.4 \\
\hline $36-40$ & 28 & 21.9 \\
\hline$>40$ & 6 & 4.7 \\
\hline \multicolumn{3}{|c|}{ Mean $\pm \mathrm{SD}=35.38 \pm 3.84$ weeks; Range $=20-42$ weeks } \\
\hline \multicolumn{3}{|c|}{ Booking status } \\
\hline Booked & 95 & 74.2 \\
\hline Un booked & 33 & 25.8 \\
\hline \multicolumn{3}{|l|}{ Mode of delivery } \\
\hline SVD & 28 & 21.9 \\
\hline CS & 97 & 75.8 \\
\hline Undelivered & 3 & 2.3 \\
\hline
\end{tabular}

Table 2: Neonatal outcome of women with preeclampsia/eclampsia at RSUTH.

\begin{tabular}{|c|c|c|}
\hline $\begin{array}{l}\text { Variables* } \\
(n=125)\end{array}$ & Frequency & $\begin{array}{l}\text { Percentage } \\
(\%)\end{array}$ \\
\hline \multicolumn{3}{|c|}{ Sex of neonate } \\
\hline Male & 63 & 50.4 \\
\hline Female & 62 & 49.6 \\
\hline \multicolumn{3}{|c|}{ Birth weight (kg) } \\
\hline$<2.5$ & 51 & 40.8 \\
\hline$\geq 2.5$ & 74 & 59.2 \\
\hline \multicolumn{3}{|c|}{ Apgar score $(n=107)$} \\
\hline$<7$ & 14 & 13.1 \\
\hline$\geq 7$ & 93 & 72.7 \\
\hline \multicolumn{3}{|c|}{$\overline{\text { SCBU }}$ admission $(\mathrm{n}=107)$} \\
\hline Yes & 54 & 50.5 \\
\hline No & 53 & 49.5 \\
\hline
\end{tabular}

*3 $(2.3 \%)$ of the women were not delivered of their babies. Out of the $125(97.7 \%)$ babies delivered, 18 (14.4\%) were still birth; $13(10.4 \%)$ males and $5(4.0 \%)$ females.

Analysis of maternal risk factors revealed a statistically significance difference in age of women and occurrence of preeclampsia/eclampsia $(\mathrm{p}=0.00001)$, as well as educational level of the mothers $(p=0.004)$, booking status of the women $(\mathrm{p}=0.0001)$, and method of delivery $(\mathrm{p}=0.016)$. There was however no statistically significant difference in the occurrence of preeclampsia/eclampsia and the parity of the women $(p=0.067)$ and the gestational age at delivery $(\mathrm{p}=1.000)$ (Table 3$)$.

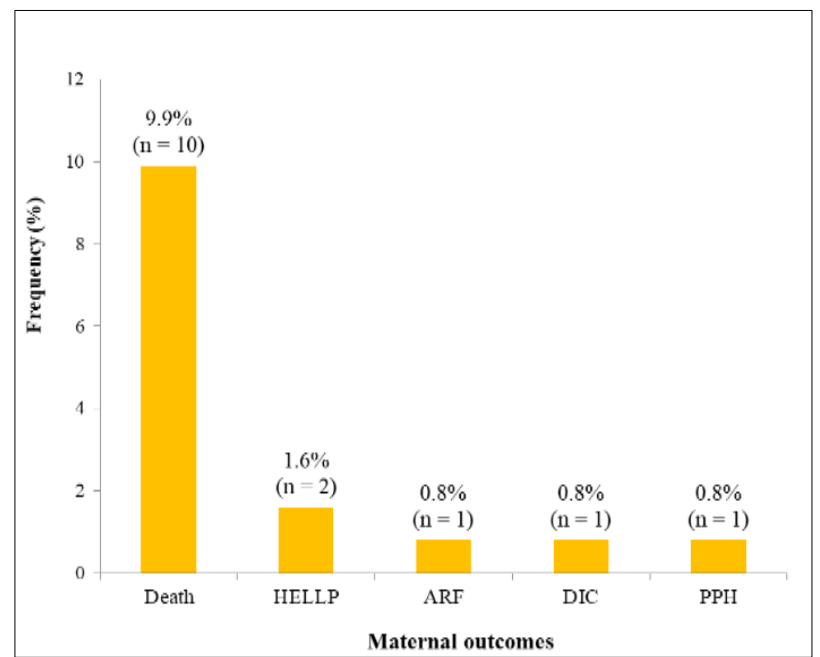

Figure 2: Maternal outcomes among women with preeclampsia/eclampsia at $\operatorname{RSUTH}(n=15)$.

Regarding neonatal outcome, there was a statistically significant difference in the Apgar scores of the neonates and the occurrence of preeclampsia and eclampsia $(\mathrm{p}=0.039)$, while there was no statistically significant difference in the occurrence of preeclampsia/eclampsia and the sex of baby $(p=0.200)$, the birth weight of baby $(\mathrm{p}=0.694)$ and admission to SCBU $(\mathrm{p}=0.397)$ (Table 4). 
Table 3: Maternal risk factors associated with occurrence of pre-eclampsia and eclampsia among women delivering at RSUTH.

\begin{tabular}{|c|c|c|c|}
\hline Variables $(n=128)$ & Severe pre-eclampsia n (\%) & Eclampsia n (\%) & Total n (\%) \\
\hline \multicolumn{4}{|l|}{ Age (year) } \\
\hline$<20$ & $0(0.0)$ & $6(100.0)$ & $6(100.0)$ \\
\hline $20-29$ & $36(69.2)$ & $16(30.8)$ & $52(100.0)$ \\
\hline $30-39$ & $56(82.4)$ & $12(17.6)$ & $68(100.0)$ \\
\hline$\geq 40$ & $2(100.0)$ & $0(0.0)$ & $2(100.0)$ \\
\hline \multicolumn{4}{|c|}{ Fisher's exact test $=17.541 ; \mathrm{p}$ value $=0.0001^{*}$} \\
\hline \multicolumn{4}{|c|}{ Educational level } \\
\hline Primary & $26(60.5)$ & $17(39.5)$ & $43(100.0)$ \\
\hline Secondary & $42(72.4)$ & $16(27.6)$ & $58(100.0)$ \\
\hline Tertiary & $26(96.3)$ & $1(3.7)$ & $27(100.0)$ \\
\hline \multicolumn{4}{|c|}{ Chi square $=10.973 ; \mathrm{p}$ value $=0.004^{*}$} \\
\hline \multicolumn{4}{|c|}{ Parity } \\
\hline Para 1 & $48(65.8)$ & $25(34.2)$ & $73(100.0)$ \\
\hline Para 2-4 & $44(83.0)$ & $9(17.0)$ & $53(100.0)$ \\
\hline Para $\geq 5$ & $2(100.0)$ & $0(0.0)$ & $2(100.0)$ \\
\hline \multicolumn{4}{|c|}{ Fisher's exact test $=5.011 ; \mathrm{p}$ value $=0.067$} \\
\hline \multicolumn{4}{|c|}{ Gestational age at delivery (week) } \\
\hline$\leq 36$ & $68(72.3)$ & $26(27.7)$ & $94(100.0)$ \\
\hline $36-40$ & $21(75.0)$ & $7(25.0)$ & $28(100.0)$ \\
\hline$>40$ & $5(83.3)$ & $1(16.7)$ & $6(100.0)$ \\
\hline \multicolumn{4}{|c|}{ Fisher's exact test $=0.266 ; \mathrm{p}$ value $=1.000$} \\
\hline \multicolumn{4}{|c|}{ Booking status } \\
\hline Booked & $79(83.2)$ & $16(16.8)$ & $95(100.0)$ \\
\hline Un booked & $15(45.5)$ & $18(54.5)$ & $33(100.0)$ \\
\hline \multicolumn{4}{|c|}{ Chi square $=17.848 ; p$ value $=0.0001^{*}$} \\
\hline \multicolumn{4}{|c|}{ Mode of delivery } \\
\hline SVD & $16(57.1)$ & $12(42.9)$ & $28(100.0)$ \\
\hline $\mathrm{CS}$ & $77(79.4)$ & $20(20.6)$ & $97(100.0)$ \\
\hline Undelivered & $1(33.3)$ & $2(66.7)$ & $3(100.0)$ \\
\hline
\end{tabular}

*Statistically significant.

Table 4: Neonatal risk factors associated with occurrence of pre-eclampsia and eclampsia among women delivering at RSUTH.

\begin{tabular}{|c|c|c|c|}
\hline Variables $(n=125)$ & Severe pre-eclampsia n (\%) & Eclampsia n (\%) & Total n (\%) \\
\hline \multicolumn{4}{|l|}{ Sex of baby } \\
\hline Male & $50(79.4)$ & $13(206)$ & $63(100.0)$ \\
\hline Female & $43(69.4)$ & $19(30.6)$ & $62(100.0)$ \\
\hline \multicolumn{4}{|c|}{ Chi square $=1.644 ; p$ value $=0.200$} \\
\hline \multicolumn{4}{|c|}{ Birth weight $(\mathrm{kg})$} \\
\hline$<2.5$ & $37(72.5)$ & $14(27.5)$ & $51(100.0)$ \\
\hline$\geq 2.5$ & $56(75.7)$ & $18(24.3)$ & $74(100.0)$ \\
\hline \multicolumn{4}{|c|}{ Chi square $=0.155 ; \mathrm{p}$ value $=0.694$} \\
\hline \multicolumn{4}{|c|}{ Apgar score $(n=107)$} \\
\hline$<7$ & $7(50.0)$ & $7(50.0)$ & $14(100.0)$ \\
\hline$\geq 7$ & $74(79.6)$ & $19(20.4)$ & $93(100.0)$ \\
\hline \multicolumn{4}{|c|}{ Fisher's exact $\mathrm{p}$ value $=0.039^{*}$} \\
\hline \multicolumn{4}{|c|}{ SCBU admission $(n=107)$} \\
\hline Yes & $39(72.2)$ & $15(27.8)$ & $54(100.0)$ \\
\hline No & $42(79.2)$ & $11(20.8)$ & $53(100.0)$ \\
\hline Chi square $=0.717$ & & & \\
\hline
\end{tabular}


Maternal death, $10(9.9 \%)$, was the most common maternal complication, followed by HEELP syndrome 2 $(1.6 \%)$ and then ARF, disseminated intravascular coagulopathy (DIC) and postpartum haemorrhage (PPH), each occurring with $1(0.8 \%)$. Stillbirth occurred in 18 $(14.4 \%)$, with male babies more affected $13(72.2 \%)$ than female babies $5(4.0 \%)$ (Figures 2 and 3). The case fatality rate was $7.8 \%$ and maternal mortality ratio for the two years was 222.4 per 100,000 women (Table 5).

Table 5: Maternal mortality during the 2-year period.

\begin{tabular}{|lll|} 
Time period & $\begin{array}{l}\text { Total number of } \\
\text { deliveries }\end{array}$ & $\begin{array}{l}\text { Number of } \\
\text { maternal deaths }\end{array}$ \\
\hline $\mathbf{2 0 1 8}$ & 2294 & 7 \\
\hline $\mathbf{2 0 1 9}$ & 2202 & 3 \\
\hline Total & 4496 & 10 \\
\hline
\end{tabular}

$\mathrm{MMR}=222.4$ Per 100,000.

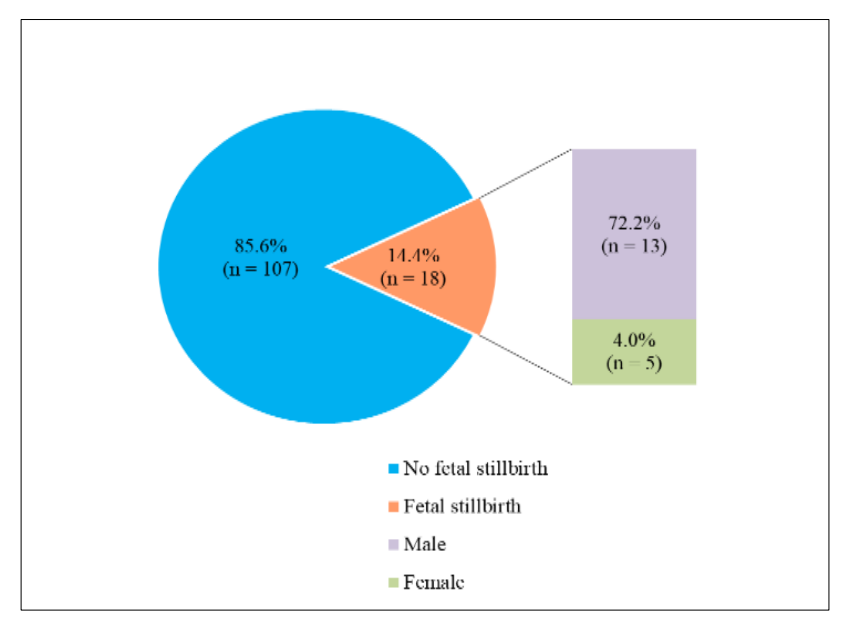

Figure 3: Perinatal outcome among women with preeclampsia/eclampsia at RSUTH.

\section{DISCUSSION}

In developing countries, pooled incidence of preeclampsia is $3.4 \% .{ }^{18}$ However recent analysis of large database from 29 countries estimates the global distribution of incidence in all deliveries to be $2.16 \%$ and $0.28 \%$ for preeclampsia and eclampsia respectively. ${ }^{19}$ The combined prevalence in this study was $2.85 \%$ with severe preeclampsia responsible for $73.4 \%(2.09 \%)$ and eclampsia $26.6 \%(0.76 \%)$, this is like the finding in the study above. The prevalence of eclampsia in this study of $0.76 \%$ is exact as the findings by Ajah et al which while higher than 0.42 and $0.44 \%$ previously reported in Kaduna and Enugu respectively, is lower than the 1.32, 1.66 and $4.4 \%$ reported in Benin, Lagos and Sokoto respectively. ${ }^{8-10,13,20,21}$

This study found a statistically significant relationship between severe preeclampsia and eclampsia with maternal age, educational status and booking status.
Older mothers $\geq 30$ years were more affected in this study which is like findings in developed world. ${ }^{22}$ This is contrary to some reports that it is significantly more in adolescents, their reason being the higher rate of early marriage and teenage pregnancy in their settings, which cannot be said of our setting., ${ }^{9,20}$ The mean and median age of mothers of 30 years, in this study is another possible explanation of difference. Various studies have found a higher prevalence in un booked mothers than Booked mothers, essentially because they were focused only on eclampsia. ${ }^{9,10,20,21}$ This study found a significant association with booked mothers as about $75 \%$ of mothers were booked and had severe preeclampsia. Majority of eclamptic cases were unbooked mothers.

Nulliparity is strongly associated with severe preeclampsia and eclampsia as reported by previous studies. ${ }^{9,10,20}$ Despite our study population being $57 \%$ primipara, with the median parity 1 , the difference in the association between parity and severe preeclampsia and eclampsia was however not statistically significant. The higher risk of preterm delivery among patients with severe preeclampsia and eclampsia, has been attributed to the interventional care and early delivery usually given to these patients after stabilization, and is also practiced in this study center. Despite the finding of more preterm births, its association with severe preeclampsia and eclampsia was not statistically significant.

The statistically significantly higher caesarean delivery rate in this study is similar to other previous studies and can be explained due to the emergency delivery approach usually adopted especially in presence of an unfavourable cervix, to avert further maternal and perinatal complications. ${ }^{11,20,23}$ Strong association of severe preeclampsia and eclampsia with low birth weight, usually thought to be due to the interventional delivery and possible intrauterine growth restriction, was not statistically significant in this study.

The maternal mortality (case fatality) rate of $7.8 \%$ in this study was lower than the findings from previous studies from Nigeria, such as 9\% from Ibadan, $12.1 \%$ from Abakaliki and $15.6 \%$ from Benin. ${ }^{8,9,20}$ Other maternal complications included HELLP syndrome in 2, ARF in 1, DIC in 1 and PPH in 1 . These are far lower than the 5, 12, 18 and 38 respectively, reported by Saxena $\mathrm{N}$ et al in a similar number of cases, though they reported less maternal deaths of $4 .{ }^{24}$ All the maternal deaths in this study, however, must have occurred following one or more of these complications but were not recorded.

The perinatal mortality (stillbirth) rate in this study of $14.4 \%$ is higher than the $10 \%$ reported from Ibadan, but lower than the 22.7 and $40.9 \%$ reported from Abakaliki and Kaduna, respectively. ${ }^{8,11,20}$ The relatively lower perinatal mortality may be attributable to the fact that low birth weight $(<2.5 \mathrm{~kg})$ babies were only $40 \%$ in this study. The positive association between low birth weight and perinatal mortality has previously been reported. ${ }^{20,25}$ 
There was also a finding of significant association of Apgar score and the cases in this study, with majority having good scores (>7), while admission to intensive care (SCBU) was not significant.

Limitations of this study were the retrospective design, with its inherent limitations and weaknesses, and that long-term perinatal complications were not addressed.

\section{CONCLUSION}

The prevalence of severe preeclampsia and eclampsia in this study was high, with associated unacceptably high maternal mortality and stillborn rates. Timely and appropriate intervention including primary management and judicious termination of pregnancy will help reduce mortality of both mother and fetus. The relatively lower mortality figures in our center was possibly due to widespread use of magnesium sulphate, timely delivery, and good obstetrics care facilities available.

\section{ACKNOWLEDGMENTS}

The authors would like to thank contributions of the interns and resident doctors who voluntarily assisted in retrieving data from case notes and birth registers.

\section{Funding: No funding sources}

Conflict of interest: None declared

Ethical approval: The study was approved by RSUTH Research and Ethics Committee (RSUTH/REC/2020008)

\section{REFERENCES}

1. Gabbe SG. Obstetrics: normal and problem pregnancies. $6^{\text {th }}$ ed. Philadelphia: Saunders, an imprint of Elsevier Inc. 2012.

2. Sibai BM. Diagnosis and management of gestational hypertension and preeclampsia. Obstet. Gynecol. 2003;102(1):181-92.

3. Sibai B, Dekker G, Kupferminc M. Pre-eclampsia. Lancet. 2005;365(9461):785-99.

4. Reingardiene D. Preeclampsia and eclampsia. Medicina (Kaunas). 2003;39(12):1244-52.

5. Sibai BM. Diagnosis, prevention, and management of eclampsia. Obstet Gynecol. 2005;105(2):402-10.

6. Tubbergen P, Lachmeijer AM, Althuisius SM, Vlak ME, Geijn HP, Dekker GA. Change in paternity: a risk factor for preeclampsia in multiparous women? J Reprod Immunol. 1999;45(1):81-8.

7. Carty DM, Delles C, Dominiczak AF. Preeclampsia and future maternal health. J Hypertens. 2010;28:1349-55.

8. Onwuhafua PI, Onwuhafua A, Adze J, Mairami Z. Eclampsia in Kaduna State of Nigeria. A proposal for better outcome. Niger J Med. 2001;10(2):81-84.

9. Okogbenin SA, Eigbefoh JO, Omorogbe F, Okonta PI, Ohihoin AG. Eclampsia in Irrua specialist teaching hospital: a five-year review. Niger J Clin Pract. 2010;13(2):149-53.
10. Akinola OI, Fabanwa AO, Gbagesin A, Ottun TA, Kusemiju OA. Improving the clinical outcome in cases of eclampsia: the experience at Lagos State university teaching hospital, Ikeja. Int J Third World Med. 2008;6(2):2.

11. Oladokun A, Okewole AI, Adewole IF, Babarinsa IA. Evaluation of cases of eclampsia in university college hospital Ibadan over a 10-year period. West Afr J Med. 2000;19(3):92-4.

12. Tukur J. The use of magnesium sulphate for the treatment of severe preeclampsia and eclampsia. Ann Afr Med. 2008;8:76-80.

13. Airede LR, Ekele BA. Adolescent maternal mortality in Sokoto, Nigeria. J Obstet. Gynaecol. 2003;23(2):163-5.

14. Ujah IA, Asien OA, Aisien OA, Mutihir JT, Vanderjagt DJ, Glew RH et al. Maternal mortality among adolescent women in Jos, North-Central, Nigeria. J Obstet. Gynaecol. 2005;25(1):3-6.

15. Awoyesuku PA, MacPepple DA, Altraide BO. Magnitude and Trends in Maternal Mortality and Causative factors: A 7-year review at a tertiary hospital in Port Harcourt, Nigeria. J Adv Med Res. 2020;32(1):103-9.

16. Magpie Trial Collaborative Group. Do women with pre-eclampsia and their babies benefit from magnesium sulphate? The magpie trial: a randomized placebo-controlled trial. Lancet. 2002;359:1877-90.

17. Onuh OS, Aisien OA. Maternal and fetal outcome in eclamptic patients in Benin City, Nigeria. J Obstet. Gynaecol. 2004;24:765-8.

18. Dolea C, AbouZahr C. Global burden of hypertensive disorders of pregnancy in the year 2000. GBD Working Paper, World Health Organization; Geneva. http://www.who.int/evidence/bod. Accessed on $8 / 8 / 2020$.

19. Abalos E, Cuesta C, Carrol G, Qureshi Z, Widmer M, Vogel JP et al. Pre-eclampsia, eclampsia, and adverse maternal and perinatal outcome: a secondary analysis of the World Health Organization Multicountry Survey on Maternal and Newborn Health. BJOG. 2014;121:14-24.

20. Ajah LO, Ozonu NC, Ezeonu PO, Lawani LO, Obuna JA, Onwe EO. The Feto-Maternal Outcome of Preeclampsia with Severe Features and Eclampsia in Abakaliki, South-East Nigeria. J Clin Diag Res. 2016;10(9):QC18-21.

21. Okafor UV, Ezegwu HU. Cesarean delivery in preeclampsia and seasonal variation in a tropical rainforest belt. J Postgrad Med. 2010;56:21-3.

22. Duley L. Pre-eclampsia and the hypertensive disorders of pregnancy. Br Med Bull. 2003;67:16176.

23. Abate MM, Lakew Z. Eclampsia: A 5-year retrospective review of 216 cases managed in 2 teaching hospitals in Addis Ababa. Ethiop Med J. 2006;44(1):27-31.

24. Saxena N, Bava AM, Nandanwar Y. Maternal and perinatal outcome in severe preeclampsia and 
eclampsia. Int J Reprod Contracept Obstet Gynecol. 2016;5:2171-6.

25. Yasmin S, Osrin D, Paul E, Costello A. Neonatal mortality of low birth weight infants in Bangladesh. Bull WHO. 2001;79:608-14.
Cite this article as: Awoyesuku PA, John DH, Lebara LB. Maternal and perinatal outcome in severe preeclampsia and eclampsia at the rivers state university teaching hospital, Nigeria. Int J Reprod Contracept Obstet Gynecol 2020;9:4382-8. 